\title{
MULTI-TRAIT EVALUATION OF VALUE FOR CULTIVATION AND USE OF EARLY MATURING EDIBLE POTATO CULTIVARS REGISTERED IN POLAND
}

\author{
Katarzyna Rymuza ${ }^{1}$ \\ 1 Department of Quantitative Methods and Spatial Management, University of Natural Sciences and Huma- \\ nities in Siedlce, Prusa 14, 08-110 Siedlce, Poland, e-mail: katarzyna.rymuza@uph.edu.pl
}

Received: 2014.08.14

Accepted: 2014.10.17

Published: 2015.01.02

\begin{abstract}
The work presents an analysis of diversity and comparison of value for cultivation and use of early maturing potato cultivars registered with the Polish National Register of Cultivars. The comparison was based on 17 yield and appearance traits and quality attributes of tubers as well as their resistance to diseases. The analysis employed the following multi-dimensional statistical methods: principal component analysis and cluster analysis. The principal component analysis revealed that over $70 \%$ of the total variation was associated with the first 6 principal components. Cluster analysis yielded 4 groups of genotypes. The first group consisted of the cultivars which produced tubers with the most shallow eyes, the best flavour and the least severe darkening of raw flesh. The cultivars in the second group produced high yields and were low in starch, dry matter and glycoalkaloids. The tubers of cultivars which were classified into the third group had the highest starch, dry matter and vitamin $\mathrm{C}$ contents. However, they produced the lowest yields and were quite susceptible to most diseases. The fourth group was made up of high-yielding cultivars which tended to accumulate glycoalkaloids but were most resistant to hollow heart in tubers.
\end{abstract}

Keywords: edible potato, potato cultivar, principal component analysis, cluster analysis

\section{INTRODUCTION}

Potato (Solanum tuberosum) is one of the major crop plants cultivated worldwide due to its versatility as it is consumed fresh, in processed forms and also used for industrial processing purposes [Oruna-Concha et al. 2002, Zgórska and Grudzińska 2012]. The plant's popularity is obvious when one considers the number of potato cultivars grown worldwide (over 4000) [Hamouz et al. 2010]. The most valuable cultivars produce high and stable yields of tubers which have attractive appearance and are of good quality. Apart from sensory traits, potato quality is also influenced by dry matter, starch and vitamin $\mathrm{C}$ contents [Hamouz et al. 2006, Murnice et al. 2011, Arvanitoyannis et al. 2012]. Moreover, good quality tubers should contain no or low levels of harmful substances, glycoalkaloids in particular [Trawczyński and Wierzbicka 2011].
In Poland, like in other EU countries, cultivation of early maturing potatoes is gaining popularity [Dwoŕák et al. 2006, Hamouz at.al. 2006, Wierzbicka 2012. As a result, the number of such genotypes registered is also increasing Rykaczewska 2007]. Cultivars registered (in variety-testing experiments and post-registration testing) are evaluated with respect to many traits which are then used to prepare a cultivar description. A great number of traits makes it difficult to select a suitable cultivar. When this is the case, multi-dimensional statistical analyses may be employed and they are increasingly popular in natural sciences [Madlaina et al. 2008, Grużewska et al. 2009, Rakonjac et al. 2010, Mohamed et al. 2011, Rymuza et al. 2012]. The methods make it possible to evaluate variation of objects with respect to many traits and to separate them into groups which share similar characteristics. Principal component analysis (PCA) and cluster analysis are most frequently used to this 
end [Veronesi and Falcinelli 1988, Charmet et al. 1994, Ahmadizadeh and Felenji 2011, Arvanitoyannis et al. 2012], because, according to Pluta et al. [2012], they are most effective.

Bearing the above in mind, an attempt was made to evaluate the multi-trait diversity of value for cultivation and use of early maturing edible potato cultivars registered in Poland in 2012 and classify them, by means of cluster analysis, into groups sharing similar characteristics.

\section{MATERIALS AND METHODS}

The analysis was based on the data describing potato cultivars registered in the Register of Cultivars (National List). Research centers all over Poland conduct studies to assess the registered cultivars in terms of characteristics associated with agrotechnology and use. The results of these studies are further analysed synthetically to produce a final description of potato cultivars. The data were also used in the present work.

The following groups of traits describing a cultivar's value for cultivation and use were considered in this analysis:

- tuber yield ( $\mathrm{t} / \mathrm{ha})$;

- tuber morphological characteristics: tuber size (9-point scale), tuber shape regularity (9-point scale where 9 - perfect regularity, 1 - deformed), eye depth (9-point scale where 9 very shallow eyes, 1 - very deep eyes);

- usable and technological value: starch content (\%), dry matter content (\%); vitamin C content $(\mathrm{mg} \%)$ glycoalkaloid content $\left(\mathrm{mg} \times \mathrm{kg}^{-1}\right)$, flavour (9-point scale where 9 - delicious flavour, 1 - bad flavour, tuber unsuitable for consumption), darkening of raw and cooked (by boiling) tuber flesh (9-point scale where 9 - no darkening, a 1 - the most severe darkening), resistance to mechanical injury;

- plant resistance to diseases and pests: resistance to potato virus Y (PVY) (9-point scale where 9 - very high resistance, 1 - very low resistance), resistance to potato leafroll virus (PLRV) (9-point scale where 9 - very high resistance, 1 - very low resistance), resistance to potato blight (9-point scale where 9 - very high resistance, 1 - very low resistance), resistance to hollow heart (5-point scale where 1 very low resistance, 5 - very high resistance), and resistance to internal rust spot (5-point scale where 1 - very low resistance, 5 - very high resistance).
The analysis was based on two multi-dimensional statistical analyses: principal component analysis and cluster analysis [Badenes et al. 2000, Lotti et al. 2008]. As the variables used in the analysis had different units, they were standardised. Principal component analysis (PCA) was used to determine multi-dimensional associations between the traits studied. PCA made it possible to reduce a relatively high number of diagnostic variables to only several formal variables called principal components [Mohammadi and Prasanna 2003, Kreutzmann et al. 2011, Arvanitoyannis et al. 2012]. The number of components for consideration was selected based on the Kaiser's criterion according to which only the variables with the value of more than 1 are analysed [Iezzoni and Pritts 1991, Lotti et al. 2008]. Such components carry only the most significant information which reflects variation of the objects so they were used in the second part of the analysis - cluster analysis. The purpose of this analysis is to group objects which are similar with respect to many characteristics (variables) [Mądry et al. 2010, Pluta et al. 2012]. Euclidean distance was used as a measure of distance between objects and Ward's procedure as an agglomeration method [Nikolic et al., 2010]. The intersection point was determined applying the Mojena's rule [Rymuza and Bombik 2012].

All the calculations were performed using Statistica 10.0 PL.

\section{RESULTS AND DISCUSSION}

Following works by Arslanoglu et al. [2011 and Haydar [2007], principal component analysis and cluster analysis were used in order to examine multi-dimensional relationships between characteristics describing Solanum tuberosum L genotypes. The methods yielded groups of cultivars with similar parameters reflecting potato value for cultivation and use.

Principal component analysis demonstrated that early maturing potato quality was associated with the first six components: PC1, PC2, PC3, PC4, PC5 and PC6. The components explained over $78.34 \%$ of the total variance - that is overall multi-dimensional variation of traits (Table 1).

The first principal component, explaining over $21 \%$ of total variation, was most closely correlated with dry matter content $(r=0.858)$ and starch content $(r=0.754)$. Similar relations were 
Table 1. Factor loads, eigenvalues and proportion of the total variance in potato cultivars, as explained by the first five principal components

\begin{tabular}{|l|c|c|c|c|c|c|}
\hline \multicolumn{1}{|c|}{ Traits } & PC 1 & PC 2 & PC 3 & PC 4 & PC 5 & PC 6 \\
\hline Tuber field & -0.172 & -0.095 & 0.016 & 0.157 & -0.827 & -0.062 \\
\hline Tuber size & -0.154 & 0.232 & -0.107 & -0.071 & -0.817 & -0.037 \\
\hline Tuber shape regularity & 0.364 & 0.336 & 0.663 & -0.240 & 0.074 & 0.086 \\
\hline Eye depth & 0.008 & 0.302 & 0.772 & -0.030 & 0.430 & -0.091 \\
\hline Delicious flavour & -0.550 & 0.045 & 0.209 & 0.711 & -0.076 & 0.045 \\
\hline Darkening of raw tuber flesh & 0.063 & 0.739 & 0.369 & 0.187 & -0.296 & -0.240 \\
\hline Darkening of cooked tuber flesh & -0.532 & -0.358 & 0.453 & 0.004 & 0.140 & 0.437 \\
\hline Starch content & 0.754 & -0.058 & -0.041 & 0.061 & 0.484 & 0.102 \\
\hline Dry matter content & 0.858 & 0.038 & 0.210 & -0.129 & 0.064 & -0.194 \\
\hline Vitamin C content & 0.164 & -0.008 & 0.060 & -0.056 & -0.059 & -0.890 \\
\hline Glycoalkaloid content & 0.302 & -0.731 & 0.176 & 0.393 & -0.126 & 0.045 \\
\hline Resistance to internal rust spot & 0.105 & -0.010 & -0.021 & 0.895 & -0.074 & -0.057 \\
\hline Resistance to hollow heart & 0.200 & -0.069 & -0.317 & 0.435 & -0.533 & 0.322 \\
\hline Resistance to mechanical injury & -0.306 & 0.082 & -0.368 & 0.666 & 0.072 & 0.183 \\
\hline Resistance to potato virus Y (PVY) & 0.045 & 0.096 & -0.766 & -0.092 & 0.199 & 0.068 \\
\hline Resistance to potato leafroll virus (PLRV) & -0.241 & 0.491 & 0.041 & 0.082 & 0.189 & -0.510 \\
\hline Resistance to potato blight & -0.234 & -0.814 & -0.163 & -0.117 & 0.020 & -0.125 \\
\hline Eigenvalue principal components & 3.66 & 2.74 & 2.16 & 1.87 & 1.67 & 1.22 \\
\hline Explained proportion of tatal variance(\%) & 21.52 & 16.13 & 12.69 & 11.01 & 9.8 & 7.19 \\
\hline Comulative proportion of total vaiance \% & 21.52 & 37.65 & 50.34 & 61.35 & 71.15 & 78.34 \\
\hline
\end{tabular}

reported by Ahmadizadeh and Felenja [2011]. The values of correlation coefficients indicated that cultivars rich in starch and dry matter have got worse flavour and tend to darken after cooking (Table 2). Also, Thybo et al. [2000], Thygensen et al. [2001] and Kreutzmann et al. [2011] reported similar finding and concluded that dry matter and starch contents are the main factors determining the culinary value of potato tubers. Moreover, Murnice et al. [2011] as well as Zgórska and Grudzińska [2012] have pointed to the relationship of tuber texture and flavour with starch and dry matter content.

The second principal component, strongly associated with plant resistance to potato blight $(\mathrm{r}=-0.814)$, after-cooking darkening $(\mathrm{r}=$ $0.739)$ and glycoalkaloid content $(-0.731 \mathrm{mg})$, explained over $16 \%$ of total variation. Potato tubers whose raw flesh tended to darken were also less resistant to potato blight and had higher glycoalkaloid contents. Negative correlation of raw tuber darkening and resistance to potato blight with PC2 can be explained by the fact that pathogen-resistant tubers contain more phenolic compounds, in particular chlorogenic acid and tyrosine [Styszko, 2001, 2004].
The third principal component is mainly the carrier of information about tuber morphological characteristics (eye depth and regularity of shape) which are very important from consumer's point of view [Styszko et al., 2003]. What is more, the component is quite strongly correlated with resistance to potato virus Y (-0.766). Cultivars which have tubers more regular in shape are usually more shallow-eyed but less resistant to PVY.

The fourth principal component, accounting for $11 \%$ of total variation, was predominantly correlated with resistance to internal rust spot $(r=0.895)$, flavour $(r=0.711)$ and resistance to mechanical injury $(\mathrm{r}=0.666)$. Potato tubers with better flavour are more susceptible to internal rust spot and mechanical injury. PC5 explained only under $10 \%$ of the total variation of genotypes studied and is strongly correlated with yield ( $\mathrm{r}=$ $0.827)$ and tuber size $(\mathrm{r}=0.817)$. The last component, which explained only $7 \%$ variability, carried information about vitamin $\mathrm{C}$ content $(\mathrm{r}=-0.890)$ and resistance to PVY $(r=-0.510)$.

The cluster analysis, based on the above-discussed principal components, yielded a dendrogram presented in Figure 1. 


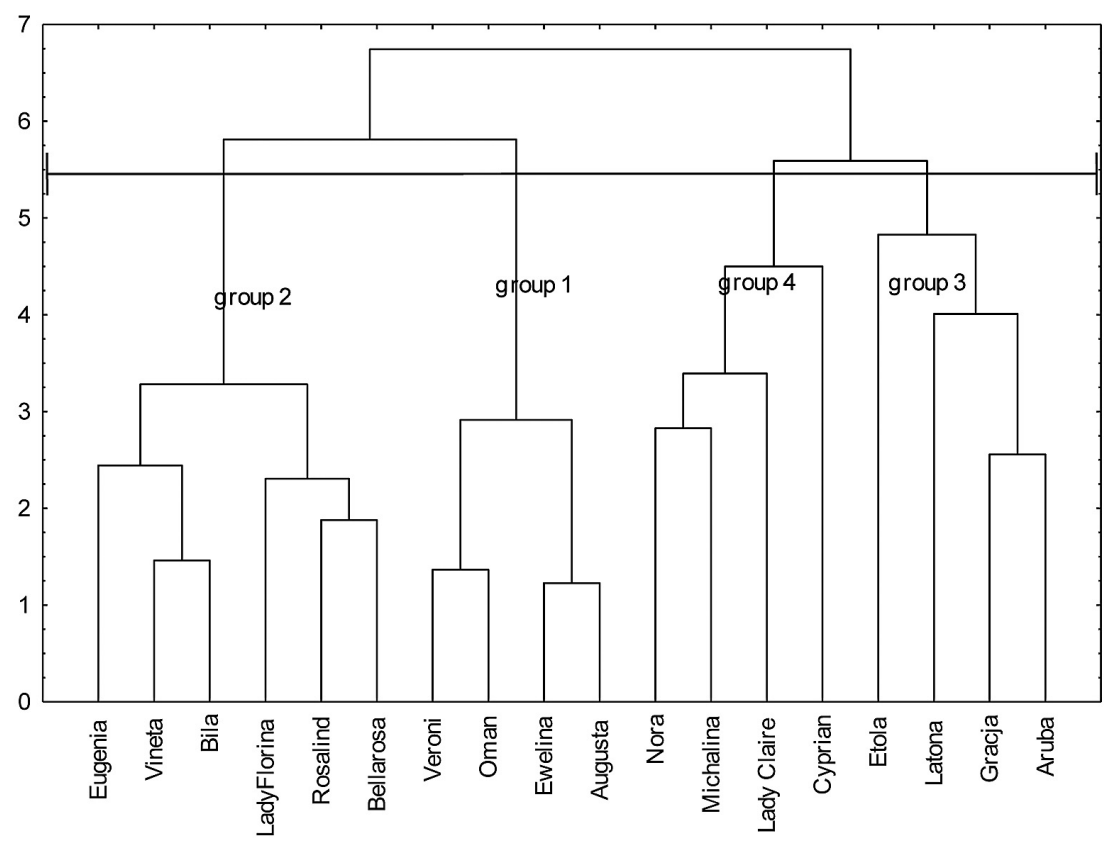

Figure 1. Dendrogram for the 18 cultivars obtained for the first six principal components

The cultivars were divided into 4 groups with different properties. Mean values of traits for each group are compiled in Table 2. Figure 2 shows spatial variation of the cultivars as influenced by the first three components, which explained over $50 \%$ of the total variation. The first group was made up of two German cultivars (Augusta, Ewelina), one Polish cultivar (Oman) and one Dutch cultivar (Veroni) (Table 3). The cultivars were slightly (positively or negatively) associated with
PC1, PC2 and PC3. They had the most shallow eyes (7.55, on average), the best flavour (7.20 on average) and their raw flesh darkened least (7.95), which indicates that they are the best cultivars for consumption when fresh and for processing [Tarant, 2005, Chotkowski and Rembeza, 2005]. Other characteristics of this cultivar included the highest resistance of tubers to internal rust spot (4.75) and mechanical injury (7.0), and the highest susceptibility to potato virus Y (4.35).

Table 2. Means of the observed traits for the potato cultivars for the four groups distinguished by the cluster analysis

\begin{tabular}{|l|c|c|c|c|}
\hline & Group 1 & Group 2 & Group 3 & Group 4 \\
\hline Tuber field & 37.10 & 38.67 & 35.95 & 41.13 \\
\hline Tuber size & 7.75 & 8.42 & 7.63 & 8.25 \\
\hline Tuber shape regularity & 7.30 & 7.22 & 7.33 & 7.15 \\
\hline Eye depth & 7.55 & 7.18 & 7.15 & 7.03 \\
\hline Delicious flavour & 7.20 & 7.02 & 6.55 & 6.95 \\
\hline Darkening of raw tuber flesh & 7.95 & 7.93 & 7.03 & 6.73 \\
\hline Darkening of cooked tuber flesh & 8.43 & 8.17 & 7.88 & 8.68 \\
\hline starch content & 12.95 & 12.58 & 14.28 & 13.15 \\
\hline Dry matter content & 20.60 & 19.78 & 22.58 & 20.48 \\
\hline Vitamin C content & 20.80 & 18.78 & 22.20 & 16.78 \\
\hline Glycoalkaloid content & 74.25 & 38.17 & 71.50 & 90.25 \\
\hline Resistance to internal rust spot & 4.75 & 3.83 & 3.50 & 3.75 \\
\hline Resistance to hollow heart & 3.75 & 4.17 & 3.75 & 4.50 \\
\hline Resistance to mechanical injury & 7.00 & 6.83 & 5.00 & 5.75 \\
\hline Resistance to potato virus Y (PVY) & 4.35 & 6.42 & 6.38 & 5.50 \\
\hline Resistance to potato leafroll virus (PLRV) & 6.50 & 6.58 & 5.88 & 4.50 \\
\hline Resistance to potato blight & 3.00 & 2.67 & 3.50 & 3.50 \\
\hline
\end{tabular}


Table 3. List of the potato cultivars, their geographic origins and their assigment to homogenous group, as by cluster analysis

\begin{tabular}{|l|l|c|c|l|c|c|c|}
\hline \multicolumn{1}{|c|}{ Cultivar } & Year & Country of origin & Group number & \multicolumn{1}{|c}{ Cultivar } & Year & Country of orgin & Group number \\
\hline Aruba & 2007 & Poland & 3 & Lady Claire & 2001 & Holand & 4 \\
\hline Augusta & 2003 & German & 1 & LadyFlorina & 2004 & Holand & 2 \\
\hline Bellarosa & 2006 & German & 2 & Latona & 1997 & Holand & 3 \\
\hline Bila & 1994 & Poland & 2 & Michalina & 2010 & Poland & 4 \\
\hline Cyprian & 2007 & Poland & 4 & Nora & 2003 & Greman & 4 \\
\hline Etola & 2009 & Poland & 3 & Oman & 2005 & Poland & 1 \\
\hline Eugenia & 2006 & Poland & 2 & Rosalind & 2001 & German & 2 \\
\hline Ewelina & 2006 & German & 1 & Veroni & 2005 & Holand & 1 \\
\hline Gracja & 2002 & Poland & 3 & Vineta & 1999 & German & 2 \\
\hline
\end{tabular}

The second group consisted of cultivars which were only slightly correlated with PC1 and PC2, and moderately and positively associated with the third principal component. The group included three German cultivars: Bellarosa, Rosalind and Vinieta, two Polish cultivars: Bila and Eugenia, and Lady Florina - a Dutch cultivar. They are high-yielding varieties $(38.67 \mathrm{t} / \mathrm{ha})$ which produce large tubers (8.42) with low starch, dry matter and glycoalkaloid contents $(12.58 \%, 19.78 \%$ and $38.17 \mathrm{mg} / \mathrm{kg}$, respectively). It is assumed that the levels of glycoalkaloids in tubers should not exceed $200 \mathrm{mg} / \mathrm{kg}$ [Friedman and Mc Donald 1997 Hall 1992]. A low tendency for these cultivars to accumulate TGA indicates that it is unlikely that dangerous concentrations of glycoalkaloids could be exceeded in potato under field conditions of production [Trawczyński and Wierzbicka 2011]. The cultivars in this group are quite resistant to potato virus $Y$, potato leafroll virus and mechanical injury but, at the same time, susceptible to potato blight (2.67) (table 2,3, fig.1)

As shown in Figure 2, most cultivars in the third group are highly and negatively correlated with $\mathrm{PC} 1$ and positively correlated with $\mathrm{PC} 2$. Tubers of these cultivars are quite tasty 6.55 ), tend to darken after cooking (7.88) and accumulate most starch (14.28\%), dry matter (22.58\%) and vitamin $\mathrm{C}(22.20 \mathrm{mg} \%)$. However, their yields are the lowest and they are most susceptible to internal rust spot, hollow heart and mechanic injury.

Cultivars in the fourth group were positively correlated with PC1 and PC2 and negatively associated with PC3. The group was made up of the following cultivars: Nora, Michalina, Lady Clarine and Cyprian. They produced the highest yields $(41.13 \mathrm{t} / \mathrm{ha})$ of tubers with the least after-cooking discolouration (8.68) and low resistance to potato

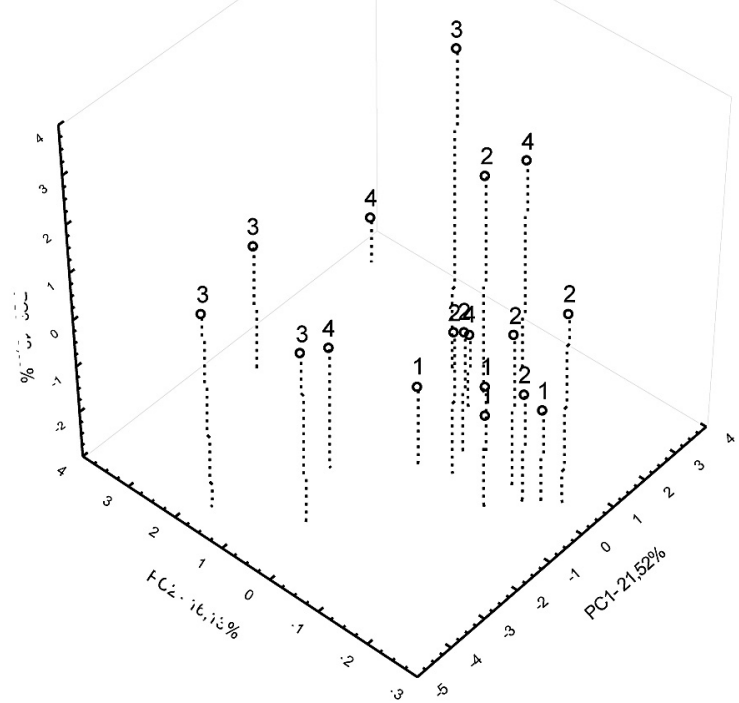

$1,2,3,4$ - espective signs denote cultivars assigned to particular groups identified by cluster analysis

Figure 2. Dystrybution of 18 potato cultivars terms of 17 traits in the system of the three components

leafroll virus $(4,50)$ which tended to accumulate most glycoalkaloids (90.25) and were most resistant to hollow heart (4.50). The considerably high yield potential is clear a evidence of the fact that breeding progress makes it possible to create genotypes which give stable crops under favourable conditions irrespective of geographical location: Michalina and Cyprian are Polish cultivars, Lady Clarine is a Dutch cultivar and Nora is a German cultivar (Table 2, 3 and Figure 1,2).

\section{CONCLUSION}

The analytical tools presented here are useful when one wants to conduct a complex and detailed analysis of trait diversity among cultivars. 
These tool make it possible to classify genotypes simultaneously in terms of many characteristics and describe them (typology). Cultivar classification makes it easier to choose the best cultivars depending on their use, e.g.: to produce chips, crisps or to grow organic potatoes.

\section{REFERENCES}

1. Ahmadizadeh M., Felenji H., 2011. Evaluating diversity among potato cultivars using agro-morphological and yield components in fall cultivation of Jiroft area. American-Eurasin Journal of Agricultural and Environmental Science, 11(5), 655-662.

2. Arslanoglu F., Aytac S., Karaca-Oner E., 2011. Morphological characterization of the local potato (Solanum tuberosum L.) genotypes collected from Eastern Black Sea region of Turkey. African Journal of Biotechnology, 10(6), 922-932.

3. Arvanitoyannis I.S., Mavromatis A.G., Vaitsi O., Korkovelos A., Golia E., 2012. Effect of genotype and geographical origin on potato properties (physical and sensory) for authenticity purposes. Journal of Agricultural Science, 4(4), 63-74.

4. Badenes M.L., Martinez-Calvo J., Llacer G., 1998. Analysis of apricot germplasm from the European ecogeogaphical group. Euphytica 102, 93-99.

5. Charmet G., Balfourier F., Monestiez P., 1994. Hierarchical clustering of perennial ryegrass populations with geographic contiguity constraint. Theoretical and Applied Genetic, 88, 42-48.

6. Chotkowski J., Rembeza J., 2005. Consumer Preferences and Changes in Potato Consumption. Roczniki Naukowe Stowarzyszenia Ekonomistów Rolnictwa i Agrobiznesu 7(8), 42-49 (in Polish).

7. Dwoŕák P., Homouz K., Jůzl M., Erhatova D., 2006. Influence of row covering with non-woven textile on tubers quality in early potatoes. Zeszyty Problemowe Postępów Nauk Rolniczych, 511, 225-231.

8. Friedman M., McDonald G.M., 1997. Potato glycoalkaloids: chemistry, analysis, safety and plant physiology. Critical Reviews in Plant Sciences, 16, 55-132.

9. Grużewska A., Biesiada-Drzazga B., Markowska M., 2009. An application of multidimensional comparative analysis in research on broiler chicken commercial lines. Archiv für Geflugelkunde, 73, 132-138.

10. Hall R.L., 1992. Toxicological burdens and the shifting burden of toxicology. Food Technology, 46, 109-114.

11. Hamouz K., Lachman J., Dvořák P., Trnková E., 2006. Influence of non-woven fleece on the yield formation of early potatoes. Plant, Soil and Environment, 52 (7), 289-294.
12. Hamouz K., Lachman J., Hajtmánkoa K., Pazderul M., Ćižek M, Dvořak P., 2010. Effect of natural and growing conditions on the content of phenolics in potatoes with different flesh colour. Plant, Soil and Environment, 56, 368-374.

13. Haydar A., Ahmed A.B., Hannan M.M., Razvy M.A., 2007. Analysis of genetic diversity in some potato varieties grown in Bangladesh. Middle East Journal of Scientific Research, 2(3-4), 143-145.

14. Iezzoni A.F., Pritts M.P., 1991. Application of principal components analysis to horticultural research. Horticulturae Science, 26(4), 334-338.

15. Kreutzmann S., Bassompierre M., Kistrup A., Buch L., Engelsen S.B., 2011. Exploratory study of potato cultivar differences in sensory and hedonistic applicability tests. Potato Research, 54, 13-28.

16. Lotti C., Marcotrigiano A.R., De Giovanni C., Resta P., Ricciardi A., Zonno V., Fanizza G., Ricciardi L., 2008. Univariate and multivariate analysis performed on bio-agronomical traits of Cucumis melo L. germplasm. Euphytica, 55, 511-522.

17. Madlaina K., Schmid P., Kölliker R., Boller B., 2008. Value of permanent grassland habitats as reservoirs of Festuca pratensis Huds. and Lolium multiflorum Lam. populations for breeding and conservation. Euphytica, 164, 239-253.

18. Mądry W., Pluta S., Sieczko L., Studnicki M., 2010. Phenotypic diversity in a sample of blackcurrant (Ribes nigrum L.) cultivars maintained in the Fruit Breeding Department at the Research Institute of Pomology and Floriculture in Skierniewice, Poland. Journal of Fruit and Ornamental Plant Research, 18, 23-37.

19. Mohamed V.O., Zein E., Fouteye M., Taleb K., Trifi M., Ali O., 2011. Use of multivariate analysis to assess phenotypic diversity of date palm (Phoenix dactylifera L.) cultivars. Scientia Horticulturae, 127, 367-371.

20. Mohammadi S.A., Prasanna B.M., 2003. Analysis of genetic diversity in crop plants - Salient statistical tools and considerations. Crop Science, 43, 1235-1248.

21. Murnice I., Karklina D., Galoburda R., Santare D., Skrabule I., Costa H.S., 2011. Nutritional composition of freshly harvested and stored Latvian potato varieties depending on traditional cooking methods. Journal of Food Composition and Analysis, 24, 699-710.

22. Nikolic D., Rakonjac V., Milatovic D., Fotiric M., 2010. Multivariate analysis of vineyard peach [Prunus persica (L.) Batsch.] germplasm collection. Euphytica, 171, 227-234.

23. Oruna-Concha M.J., Duckham S.C., Ames J.M., 2002. Comparison of the volatile components of eight cultivars of potato after microwave baking. Lebensmittel-Wissenschaft und Technologie, $35(1), 80-86$. 
24. Pluta S., Mądry W., Sieczko L., 2012. Phenotypic diversity for agronomic traits in a collection of blackcurrant (Ribes nigrum L.) cultivars evaluated in Poland. Scientia Horticulturae, 145, 136-144.

25. Rakonjac V., Fotiric A.M., Nikolic D., Milatowic D., Colic S., 2010. Morphological characterization of Oblacinska sour cherry cultivars in a germplasm bank at Portugal. Genetic Resources and Crop Evolution, 55, 593-601.

26. Rykaczewska K., 2007. Productivity of early lock and foreign potato cultivars. Zeszyty Problemowe Postępów Nauk Rolniczych, 517, 629-638 (in Polish).

27. Rymuza K., Bombik A., 2012. Comparison of edible potato cultivars by means of some methods of multidimensional analysis. Acta Scientiarum Polonorum Agricultura, 11(1), 67-77.

28. Rymuza K., Turska E., Wielogórska G., Bombik A., 2012. Use of principal component analysis for the assessment of spring wheat characteristics. Acta Scientiarum Polonorum Agricultura, 11(1), 79-90.

29. Styszko L., 2004. Breeding of starch potato cultivars with high utility parameters. Biuletyn IHAR, 232, 275-283 (in Polish).

30. Styszko L., Modzelewski T., Kamasa J., Majewski A. 2001. Relationship between morphological characteristics of potato tubers and starch content and starch yield. Zeszyty Naukowe AR Wocław, 415(80), 283-293 (in Polish).

31. Styszko L., Modzelewski T., Kamasa J., Majewski A., 2003. The relationship between a type of cook- ing quality (culinary) and morphological features of potato tubers. Biul IHAR, 226/227/2, 533-538.

32. Tarant Sz., 2005. Taste as a main criterion of food products in consumers' evaluation. Roczniki Naukowe Stowarzyszenia Ekonomiki Rolnictwa i Agrobiznesu 7(8), 267-270 (in Polish).

33. Thybo AK., Bechmann IE., Martens M., Engelsen SB., 2000. Prediction of sensory texture of cooked potatoes using uniaxial compression, near infrared spectroscopy and low field 1H NMR spectroscopy. Journal of Food Science and Technology, 33(2), 103-111.

34. Thygesen LG., Thybo AK., Engelsen SB., 2001. Prediction of sensory texture quality of cooked potatoes from low-field 1H NMR of raw potatoes. The role of chemical constituents. Journal of Food Science and Technology, 34(7), 469-477.

35. Trawczyński C., Wierzbicka A., 2011. The reaction of new potato cultivars to nitrogen fertilization. Bul. IHAR, 259, 193-201 (in Polish).

36. Veronesi F., Falcinelli M., 1988. Evaluation of an Italian germplasm collection of Festuca arundinacea Schreb. through a multivariate analysis. Euphytica, 28, 211-220.

37. Wierzbicka A., 2012. Effect of variety, harvest date and nitrogen fertilization on the content of starch and dry matter in early potatoes tubers. Fragmenta Agronomica, 29(2), 134-142 (in Polish).

38. Zgórska K., Grudzińska M., 2012. Changes in selected quality parameters of potato tubers during storage. Acta Agrophysica, 19(1), 203-214 (in Polish). 